\title{
Anita Filipczak-Białkowska*
}

\section{Obiekty ideologiczne w dyskursie parlamentarnym}

\section{Dyskurs polityczny a dyskurs parlamentarny - ustalenia terminologiczne}

Dyskurs parlamentarny tworzą wypowiedzi przedstawicieli świata polityki, wygłaszane w parlamencie. Włączany jest on do szerszego typu dyskursu, określanego przez różnych badaczy jako dyskurs polityki ${ }^{1}$ bądź dyskurs polityków ${ }^{2}$. Ta szeroka kategoria obejmuje wypowiedzi polityków w ramach ról przypisanych im w obrębie instytucji politycznych i powstaje w trakcie kontaktów polityków z politykami. Dominuje w nim forma dialogu, przeważa równorzędność rang partnerów nad brakiem równorzędności. Celem wypowiedzi najczęściej jest agitacja - jeden z partnerów skłania drugiego do zrobienia czegoś lub jest to działanie podejmowane przez obydwu partnerów interakcji. Rozumiany jako część dyskursu polityki dyskurs parlamentarny obejmuje wszelkie formy działalności komunikacyjnej członków parlamentu, wynikające z instytucjonalnych uwarunkowań sprawowanej funkcji, a więc wystąpienia w trakcie debat parlamentarnych, prace w sejmowych komisjach i podkomisjach, prace w komisjach śledczych. W artykule przedmiotem zainteresowania będą fragmenty polskich debat parlamentarnych, w których przedstawiciele poszczególnych klubów parlamentarnych dokonują prezentacji stanowisk tych klubów wobec omawianych w debacie zagadnień.

Przyjęty w artykule model opisu oparty jest na założeniach gramatyki komunikacyjnej. Zgodnie z nim debata parlamentarna, z uwagi na realizowany w niej

* Dr, Zakład Teorii i Praktyki Komunikacji, Katedra Dziennikarstwa i Komunikacji Społecznej, Uniwersytet Łódzki, e-mail: anita.filipczak@uni.lodz.pl.

1 M. Czyżewski, S. Kowalski, A. Piotrowski, Wprowadzenie, [w:] Rytualny chaos. Studium dyskursu publicznego, red. M., Czyżewski i in., Warszawa 2010, s. 15-48.

2 E. Laskowska, Sytuacje komunikacyjne w dyskursach politycznych, [w:] Języka a komunikacja 4: Nowe oblicza komunikacji we współczesnej polszczyźnie, red. G. Szpila, Kraków 2002, s. 175-182. 
cel komunikacyjny, należy do stylu mieszanego. Elżbieta Laskowska stwierdziła, że „niemożliwe jest porozumiewanie się w parlamencie bez perswazji”" ka postrzega parlament przede wszystkim przez pryzmat jego funkcji, jaką jest tworzenie prawa - posłowie i senatorowie tworzą prawo poprzez uchwalanie aktów prawnych drogą głosowania. Warto podkreślić, że w literaturze przedmiotu przyjmuje się nieco idealistyczne założenie, że każdy z posłów znajduje w sobie wystarczającą motywację do poszukiwania informacji na temat przedmiotu debaty, na ich podstawie podejmuje świadomą decyzję o tym, jak będzie głosował: za, przeciw czy wstrzyma się od głosu, może także nie uczestniczyć w głosowaniu. Na tym tle ujawnia się istotna funkcja debaty parlamentarnej, po pierwsze - pozwalającej parlamentarzystom na zapoznanie się z przedmiotem sprawy, nad którą planowane jest głosowanie, a po drugie - pomagającej poszczególnym parlamentarzystom podjąć decyzję co do kierunku głosowania ${ }^{4}$. Jak zauważa Laskowska, „W wypowiedziach parlamentarnych realizuje się [...] artykulacja interesów, która składa się z kilku faz. Po ujawnieniu się potrzeb i przeobrażeniu ich w postulaty następuje argumentacja, a w niej dużą rolę odgrywa odwoływanie się do norm i systemów wartości”5. To z kolei stanowi istotę działania perswazyjnego. Wysłuchanie i zinterpretowanie wypowiedzi przez uczestników debaty ma zatem zasadnicze znaczenie dla wskazanego wyżej celu komunikacyjnego realizowanego w debacie, czyli uchwalania aktów prawnych, a przez to - niebagatelny wpływ na życie obywateli danego państwa.

\section{Obiekt kulturowy, obiekt ideologiczny - założenia metodologiczne}

Zgodnie z metodologią gramatyki komunikacyjnej ${ }^{6}$ należy uznać, że w debacie parlamentarnej ma miejsce polemika aksjologiczna. Uczestnicy interakcji, poprzez stosowaną argumentację, dążą do różnych kierunków atrybucji obiektów funkcjonujących na scenie politycznej7. Każdy obiekt charakteryzuje wielość parametrów, do jakich można się odnieść przywołując je w wypowiedzi. Celem działań perswazyjnych jest redukcja tych parametrów, tak aby dany obiekt wiązał się z preferowaną przez nadawcę oceną aksjologiczną. Przedstawiciele różnych środowisk często dążą do usunięcia z zakresu znaczeniowego takiego obiektu niepożądanych z punktu widzenia ich celu perswazyjnego elementów, przez co obiekt może uzyskać nawet prze-

3 E. Laskowska, Dyskurs parlamentarny w ujęciu komunikacyjnym, Bydgoszcz 2004, s. 175.

4 Zob. tamże, s. 174.

5 Tamże, s. 174-175.

6 Zob. A. Awdiejew, Gramatyka interakcji werbalnej, Kraków 2007; A. Awdiejew, G. Habrajska, Wprowadzenie do gramatyki komunikacyjnej, t. 1-2, Łask 2004-2006.

7 A. Awdiejew, Ideologia. Postawa i komunikacja, [w:] Ideologie w słowach i obrazach, red. I. Kamińska-Szmaj i in., Wrocław 2008, s. 71. 
ciwstawne znaki wartości w dyskursie różnych grup. W świetle tych ustaleń definicja obiektu ideologicznego przyjmuje postać: obiekt ideologiczny jest typem obiektu kulturowego i konstytuuje się wówczas, gdy w ramach różnych grup społecznych (przynajmniej dwóch) przypisywane mu są przeciwne wartości.

W bazie ideologicznej każdej grupy społecznej występuje podklasa obiektów kulturowych, które różnią się od obiektów ogólnych tym, że „nawet w obrębie tej samej kultury przyjmują inną atrybucję, tworząc konkurujące ze sobą systemy ideologiczne, w których są różnie wartościowane"8. Nie jest określony sens ontologiczny obiektów ideologicznych: „obiektami kulturowymi, a więc i ideologicznymi, mogą być różne zjawiska funkcjonujące w przestrzeni ideologicznej danej grupy - osoby i zachowania się tych osób, instytucje i działania tych instytucji, zdarzenia, procesy, stany itd."9. W gramatyce komunikacyjnej podkreśla się, że do dystynktywnych cech obiektu ideologicznego należy zachodząca w jego obrębie dychotomia wartości. Jak zauważa Grażyna Habrajska: „Konfrontowanie wartościowania jest niezbędne dla zaistnienia dyskursu ideologicznego"10.

Identyfikacja obiektów ideologicznych i sposobów ich wartościowania pozwala na pełniejsze rozumienie sensu komunikatu, do przekazania którego dąży nadawca, a często dopiero dzięki tej operacji możliwe jest prawidłowe zrozumienie komunikatu. Mogłoby się wydawać, że takie obiekty, jak demokracja czy prawo do życia będą miały w polskim dyskursie parlamentarnym status obiektu kulturowego, czyli będą charakteryzowały je takie same parametry w obrębie dyskursów różnych grup. Badanie przeprowadzone w perspektywie gramatyki komunikacyjnej prowadzi do wniosku, że jest to błędne przekonanie.

\section{Obiekt ideologiczny w dyskursie parlamentarnym - procedura badawcza}

Główne pytanie badawcze, postawione w niniejszym opracowaniu, brzmi: czy w debacie parlamentarnej funkcjonują obiekty ideologiczne? Na wstępie jednak wypada zastanowić się, dlaczego identyfikowanie obiektów ideologicznych jest tak istotne $\mathrm{w}$ procesie rozumienia tego typu przekazu? Udzielenie odpowiedzi wymaga przeniesienia się na poziom interpretacji wypowiedzi. Wiedza uczestników dyskursu na temat statusu poszczególnych obiektów w dyskursie parlamentarnym, czyli umiejętność odróżnienia obiektu kulturowego od obiektu ideologicznego, pozwala uniknąć błędu ekwiwokacji. W literaturze przedmiotu terminem „ekwiwokacja” określa się „stosowanie wieloznacznego

\footnotetext{
8 Tamże, s. 67.

9 G. Habrajska, Przeżywanie ideologii, [w:] Ideologie w słowach..., s. 57.

10 Tamże, s. 57.
} 
słowa w różnych znaczeniach w tej samej dyskusji"11. Dostrzeżenie tej wieloznaczności w procesie interpretacji wypowiedzi wygłaszanych podczas debaty parlamentarnej (a także szerzej - w dyskursie politycznym) wymaga szerokiej kompetencji politycznej ${ }^{12} \mathrm{i}$ jest niezbędne w procesie badawczym, w którym nie uwzględnia się tylko formalnego uporządkowania jednostek leksykalnych, ale poddaje tekst analizie na poziomie głębokich struktur sensu. Tak postępuje się w gramatyce komunikacyjnej.

Ujawnienie występowania obiektów ideologicznych w dyskursie parlamentarnym pozwoliłoby wyciągnąć dalej idące hipotezy, na razie dość niepewne. Można założyć, że aktorzy sceny politycznej interpretują wypowiedzi innych polityków w niewłaściwy sposób, a ze znacznie większą pewnością - że niepoprawnie rozumieją te wypowiedzi przysłuchujący się temu dyskursowi obywatele. Można także przyjąć założenie, że politycy zdają sobie sprawę z możliwości wielorakiego rozumienia przywoływanych przez nich obiektów ideologicznych. Nie można jednak przesądzać w tym miejscu o tym, że uczestnicy debaty parlamentarnej posługują się nimi w sposób intencjonalny, czyli mając na celu wprowadzenie odbiorcy w błąd. Tym samym nie można także orzec, czy działanie to ma charakter perswazji czy manipulacji.

Procedurę badawczą prowadzącą do rozpoznania natury określonego obiektu kulturowego jako obiektu ideologicznego przedstawiła Habrajska w artykule pt. Przeżywanie ideologii ${ }^{13}$. Zdaniem badaczki, sądy oceniające otrzymane w wyniku analizy tekstów danej grupy należy porównać z sądami oceniającymi na temat tego obiektu w innych grupach. W przypadku, gdy analiza porównawcza wykaże, że różne grupy wybierają różne wartości dla określonego obiektu z wielu parametrów, jakie on posiada, można uznać go za obiekt ideologiczny. Jest to spójne z przedstawioną wyżej definicją obiektu ideologicznego.

Pierwszym krokiem w procesie identyfikacji obiektów ideologicznych jest wyodrębnienie sądów aksjologicznych na temat określonych obiektów z wypowiedzi reprezentantów różnych grup społecznych. W nurcie gramatyki komunikacyjnej powstało już wiele opracowań, opisujących to działanie ${ }^{14}$, również dotyczących stricte analizy treści aksjologicznych w wypowiedziach wygłoszonych $\mathrm{w}$ trakcie debaty parlamentarnej ${ }^{15}$, nie ma zatem potrzeby powtarzania zawar-

11 P. H. Lewiński, Neosofistyka. Argumentacja retoryczna w komunikacji potocznej, Wrocław 2012, S. 143.

12 Zob. A. Awdiejew, G. Habrajska, Strategie propagandowe i agitacyjne, [w:] Rozmowy o komunikacji 3: Problemy komunikacji społecznej, red. G. Habrajska, Łask 2009, s. 9-54.

13 G. Habrajska, Przeżywanie...

14 Zob. m.in.: A. Awdiejew, G. Habrajska, Wprowadzenie do gramatyki komunikacyjnej, t. 2, Łask 2006 czy A. Awdiejew, G. Habrajska, Strategie propagandowe...

15 Zob. m.in.: E. Laskowska, Dyskurs parlamentarny..., A. Filipczak, Mechanizmy manifestowania orientacji aksjologicznej na przykładzie debat parlamentarnych, [w:] Rozmowy o komunikacji 4. Metodologia i praktyka komunikacji społecznej, Łask 2008, s. 71-85; A. Filipczak-Białkowska, 
tych w tych tekstach treści. Dość przypomnieć, że sądy aksjologiczne mogą być wyrażone wprost za pomocą operatorów emotywno-oceniających, mogą mieć budowę zdań preskryptywnych, mogą manifestować się w postaci etykietowania albo tworzyć bardziej skomplikowanie konstrukcje w postaci argumentów aksjologicznych. Sądy, wyodrębnione w trakcie analizy debaty parlamentarnej, tworzą w rezultacie kolekcje sądów aksjologicznych dla poszczególnych klubów parlamentarnych.

Odnalezienie w zidentyfikowanych zbiorach sądów aksjologicznych tych, które dotyczą tego samego obiektu jest zadaniem niełatwym, które wymaga analizy wielu tekstów. W tym artykule do zilustrowania zjawiska wykorzystano wyniki uzyskane $w$ trakcie pracy nad innym problemem badawczym, jakim było skonstruowanie profilu ideologicznego poszczególnych klubów parlamentarnych funkcjonujących w Sejmie RP w okresie tzw. IV RP. Kolekcje sądów aksjologicznych zostały w nim sporządzone w oparciu o analizę 20 debat parlamentarnych z lat 2006-2007 dla sześciu klubów parlamentarnych: Prawo i Sprawiedliwość, Platforma Obywatelska, Sojusz Lewicy Demokratycznej, Samoobrona RP, Liga Polskich Rodzin i Polskie Stronnictwo Ludowe. Ze sporządzonych kolekcji wyselekcjonowano sądy aksjologiczne dotyczące tego samego obiektu, jak np. zapłodnienie in vitro, prawo do życia i inne. Ich porównanie - zgodnie z opisaną wyżej procedurą zaproponowaną przez Habrajską - pozwoliło ustalić status tego obiektu jako obiektu kulturowego bądź jako obiektu ideologicznego. W tym opracowaniu przyjmuje się, że jeśli obiekt wykaże różnicę wartościowania w zakresie sądów co najmniej dwóch partii, to może zostać uznany za obiekt ideologiczny.

\section{Obiekty ideologiczne w dyskursie parlamentarnym IV RP}

\section{a) Demokracja}

$\mathrm{Z}$ analizy przeprowadzonej dla obiektu demokracja wynika, że stanowi on w ramach badanego dyskursu obiekt ideologiczny. Analizę fragmentów dyskursu dotyczących tego obiektu zaprezentowano w Tabeli 1.

Profilowanie obiektu ideologicznego jako strategia manifestowania ideologii w debacie parlamentarnej, [w:] Komunikatywizm w Polsce - wybrane zagadnienia z teorii i praktyki, red. G. Habrajska, Łódź 2011, s. 139-145; A Filipczak-Białkowska, Niedosłowność jako strategia w tekstach politycznych - metody, funkcje, interpretacja, [w:] Język a komunikacja 37. Niedosłowność w języku, pod red. M. Odelskiego i in., Kraków 2016, s. 103-113; A. Filipczak-Białkowska, The Ideology of the Polish Political Discourse in Terms of Communicative Grammar [w:] Materiały III Międzynarodowej Konferencji Naukowo-Praktycznej "Nauka Szkoła Romana Iwanczenka", CD, Nationalnyj Tiechnicznyj Uniwersytet Ukrainy, Ukraina 2016, s. 290-300, file://C:/Users/USER/AppData/ Local/Temp/95257-200995-1-SM-1.pdf [dostęp: 12.04.2017]. 
Tabela 1. Obiekt ideologiczny demokracja w orientacji ideologicznej Sojuszu Lewicy Demokratycznej i Ligi Polskich Rodzin

\begin{tabular}{|c|c|c|c|}
\hline \multicolumn{2}{|c|}{ Sojusz Lewicy Demokratycznej } & \multicolumn{2}{|c|}{ Liga Polskich Rodzin } \\
\hline (P10/16.02/P9/SLD1) & argument & argument & $\begin{array}{c}\text { (P27/26.10/ } \\
\text { P17/LPR1) }\end{array}$ \\
\hline $\begin{array}{l}\text { (1) Panie pośle, trochę } \\
\text { skromności, trochę } \\
\text { posłuchania tego, co ma } \\
\text { do powiedzenia opozycja. } \\
\text { Dlatego że opozycja, } \\
\text { chcę panu powiedzieć, } \\
\text { w demokratycznym } \\
\text { porzadku prawnym stanowi } \\
\text { o tym, że to państwo może } \\
\text { funkcjonować. Jeżeli pan } \\
\text { tego nie zrozumie i będzie } \\
\text { zamykał usta opozycji, boję } \\
\text { się, że może się to naprawdę } \\
\text { źle skończyć dla porzadku } \\
\text { demokratycznego w Polsce. }\end{array}$ & $\begin{array}{l}\frac{\text { RO: Demokracja }}{\text { to możliwość }} \\
\text { swobodnego działania } \\
\text { opozycji. } \\
\text { SK: Prawo } \\
\text { i Sprawiedliwość chce } \\
\text { ograniczyć opozycję. } \\
\text { K: Rządy Prawa } \\
\text { i Sprawiedliwości } \\
\text { zagrażają porządkowi } \\
\text { demokratycznemu } \\
\text { w Polsce. }\end{array}$ & $\begin{array}{l}\frac{\text { RO: Demokracja to }}{\text { możliwość sprawowania }} \\
\text { przez większość } \\
\text { parlamentarną rzadów w } \\
\text { państwie na swój sposób. } \\
\text { SK: Posłowie koalicji } \\
\text { PiS-LPR-Samoobrona } \\
\text { stanowią większość } \\
\text { w parlamencie. } \\
\text { K: Sprawowanie rządów } \\
\text { na sposób koalicji } \\
\text { PiS-LPR-Samoobrona } \\
\text { jest zgodne z zasadami } \\
\text { demokracji. }\end{array}$ & $\begin{array}{l}\text { (2) Po drugie, } \\
\text { wierzymy } \\
\text { w mądrość } \\
\text { naszych postów } \\
\text { i senatorów } \\
\text { także w tej } \\
\text { ważnej sprawie, } \\
\text { oni to bowiem } \\
\text { otrzymali } \\
\text { mandat } \\
\text { zaufania od } \\
\text { społeczeństwa } \\
\text { i to oni musza } \\
\text { zrobić wszystko } \\
\text { w tej kwestii. }\end{array}$ \\
\hline
\end{tabular}

Źródło: opracowanie własne.

W przykładzie numer 1 przedstawiciel Sojuszu Lewicy Demokratycznej podkreśla konieczność uwzględnienia stanowiska opozycji w procesie sprawowania władzy, reprezentant Ligi Polskich Rodzin natomiast, funkcjonując w ówczesnej koalicji (PiS-LPR-Samoobrona RP), taką konieczność wyklucza. W obrębie obiektu kulturowego demokracja funkcjonuje wiele parametrów. W przytoczonym przykładzie każdy z nadawców odwołuje się do innego z nich, stosownie do celu, jakim jest wykazanie, czy aktualną sytuację na scenie politycznej charakteryzuje demokracja, czy też nie. Wyraźnie ujawnia się tu zatem różnica w sposobie rozumienia pojęcia demokracja, a tym samym powstaje konieczność zakwalifikowania go do obiektów ideologicznych.

b) Prawo do życia

Różnice w wartościowaniu ujawniają się także w przypadku jednego z podstawowych w cywilizowanych społeczeństwach obiektów, jakim jest prawo do życia. Ilustruje to Tabela 2 i przytoczone w niej przykłady numer 3 i 4 .

Z przedstawionej analizy można wyprowadzić wniosek, że dla Sojuszu Lewicy Demokratycznej obiekt prawo do życia jest jedną z wolności obywatelskich należnych każdemu członkowi społeczeństwa. W opinii przedstawiciela Ligi Polskich Rodzin prawo do życia zostało nadane przez Boga i jest niezależne od woli człowieka. Przypisanie tych różnych wartości do badanego obiektu każe zaliczyć go do obiektów ideologicznych. 
Tabela 2. Obiekt ideologiczny prawo do życia w orientacji ideologicznej Sojuszu Lewicy Demokratycznej i Ligi Polskich Rodzin

\begin{tabular}{|c|c|c|c|}
\hline \multicolumn{2}{|c|}{ Sojusz Lewicy Demokratycznej } & \multicolumn{2}{|c|}{ Liga Polskich Rodzin } \\
\hline $\begin{array}{c}\text { (P27/26.10/P17/ } \\
\text { SLD1) }\end{array}$ & argument & argument & (P27/26.10/P17/LPR1) \\
\hline $\begin{array}{l}\text { (3) Sojusz Lewicy } \\
\text { Demokratycznej jest } \\
\text { za ochrona życia, } \\
\text { ale - w odróżnieniu } \\
\text { od katoprawicy - nie } \\
\text { będzie tego robić } \\
\text { kosztem życia, } \\
\text { zdrowia i praw } \\
\text { kobiet. }\end{array}$ & $\begin{array}{l}\text { RO: Nie wolno } \\
\text { ograniczać wolności } \\
\text { obywatelskich żadnej } \\
\text { osoby. } \\
\text { ROD: Nie można } \\
\frac{\text { ograniczać prawa }}{\text { kobiet do życia }} \\
\text { i zdrowia. } \\
\text { SK: Zmuszanie kobiety } \\
\text { do kontynuowania } \\
\text { ciąży, która szkodzi } \\
\text { jej zdrowiu to } \\
\text { ograniczanie jej praw. } \\
\text { K: Nie wolno } \\
\text { zmuszać kobiety do } \\
\text { kontynuowania ciąży, } \\
\text { która szkodzi jej } \\
\text { zdrowiu. }\end{array}$ & $\begin{array}{l}\text { RO: Bóg decyduje } \\
\text { o życiu i śmierci. } \\
\text { ROD: Człowiek nie } \\
\text { może decydować } \\
\text { o tym, czy ma } \\
\text { przeżyć dziecko czy } \\
\text { ciężarna matka. } \\
\text { SK: Aborcja na } \\
\text { życzenie umożliwia } \\
\text { kobiecie zabicie } \\
\text { dziecka z powodu } \\
\text { ewentualnego } \\
\text { uszczerbku na jej } \\
\text { zdrowiu. } \\
\text { K: Należy zakazać } \\
\text { aborcji na życzenie. }\end{array}$ & $\begin{array}{l}\text { (4) Ja prywatnie, jako } \\
\text { osoba wierzaca, katolik } \\
\text { stojacy na stanowisku } \\
\text { konsekwentnej obrony } \\
\text { życia, nie uważam za } \\
\text { dobre i doskonate prawa, } \\
\text { które pozwala bezkarnie } \\
\text { lekarzowi zabijać } \\
\text { dziecko tylko dlatego, ze } \\
\text { zdiagnozowano u matki } \\
\text { możliwość ewentualnego } \\
\text { pogorszenia się wzroku. To } \\
\text { jest prawo niedoskonate, } \\
\text { a obecnie obowiqzujace. }\end{array}$ \\
\hline
\end{tabular}

Źródło: opracowanie własne.

c) Ograniczenie liczby aborcji

Gdyby zapytać reprezentantów dwóch partii, tj. Prawa i Sprawiedliwości oraz Sojuszu Lewicy Demokratycznej, wprost o to, jaki jest ich stosunek aksjologiczny do obiektu ograniczenie liczby aborcji, prawdopodobnie jedni i drudzy przypisaliby mu wartość pozytywną. Co do klubu Prawo i Sprawiedliwość nie ma tu najmniejszej wątpliwości, reprezentant Sojuszu Lewicy Demokratycznej zaś wypowiada w debacie taką deklarację bezpośrednio: „Sojusz Lewicy Demokratycznej chce ograniczyć liczbę przerywanych ciąż”. Sformułowania te przez obydwu polityków użyte zostają jednak w odmiennym znaczeniu. Ilustrują to twierdzenia przedstawione w miejscu reguł ogólnych w poniżej odtworzonej argumentacji aksjologicznej, jaką posłużyli się w swych wypowiedziach przedstawiciele obu partii.

Kiedy zostanie odtworzona argumentacja aksjologiczna, wyraźnie widać, że zakresy znaczeniowe, w jakich zacytowani politycy odwołują się do obiektu ograniczenie liczby aborcji są różne, a tym samym należy uznać go za obiekt ideologiczny. 
Tabela 3. Obiekt ideologiczny ograniczenie liczby aborcji w orientacji ideologicznej Sojuszu Lewicy Demokratycznej oraz Prawa i Sprawiedliwości

\begin{tabular}{|c|c|c|c|}
\hline \multicolumn{2}{|c|}{ Sojusz Lewicy Demokratycznej } & \multicolumn{2}{|c|}{ Prawo i Sprawiedliwość } \\
\hline (P27/26.10/P17/SLD1) & argument & argument & (P27/26.10/P17/PiS1) \\
\hline $\begin{array}{l}\text { (5) Sojusz Lewicy } \\
\text { Demokratycznej chce } \\
\text { ograniczyć liczbę } \\
\text { przerywanych ciąż. Jak } \\
\text { jednak to można zrobić? } \\
\text { Promując edukację } \\
\text { seksualna i rozszerzając } \\
\text { dostęp do środków } \\
\text { antykoncepcyjnych. }\end{array}$ & $\begin{array}{l}\text { RO: Trzeba } \\
\text { powstrzymać ludzi } \\
\text { przed dokonywaniem } \\
\text { nielegalnych aborcji. } \\
\text { SK: Wyposażenie spo- } \\
\text { teczeństwa w wiedzę } \\
\text { z zakresu życia seksu- } \\
\text { alnego pozwoli zmniej- } \\
\text { szyć liczbę nielegalnie } \\
\text { przerywanych ciąż. } \\
\text { K: Należy wprowa- } \\
\text { dzić edukację sek- } \\
\text { sualną. }\end{array}$ & $\begin{array}{l}\frac{\text { RO: Trzeba }}{\text { powstrzymać ludzi od }} \\
\frac{\text { dokonywania aborcji }}{\text { bez względu na }} \\
\text { powód. } \\
\text { SK: Wprowadzenie } \\
\text { prawa zakazującego } \\
\text { aborcję powstrzyma } \\
\text { ludzi od dokonywa- } \\
\text { nia aborcji. } \\
\text { K: Należy wprowa- } \\
\text { dzić absolutny zakaz } \\
\text { aborcji. }\end{array}$ & $\begin{array}{l}\text { (6) Po wprowadzeniu } \\
\text { ustawy o planowaniu } \\
\text { rodziny nie nastapiło } \\
\text { nic strasznego, wręcz } \\
\text { przeciwnie [...], } \\
\text { zmniejszyła się także, } \\
\text { i to radykalnie, liczba } \\
\text { tzw. aborcji, co jest } \\
\text { skutkiem wzrostu } \\
\text { społecznej świadomości } \\
\text { wielkiej wartości życia } \\
\text { ludzkiego [...]. }\end{array}$ \\
\hline
\end{tabular}

Źródło: opracowanie własne.

d) Zapłodnienie in vitro

Poniżej przedstawione są sądy aksjologiczne przedstawicieli dwóch klubów parlamentarnych wobec obiektu zapłodnienie in vitro.

Tabela 4. Obiekt ideologiczny zapłodnienie in vitro $w$ orientacji ideologicznej Sojuszu Lewicy Demokratycznej oraz Prawa i Sprawiedliwości

\begin{tabular}{|c|c|c|c|}
\hline \multicolumn{2}{|c|}{ Sojusz Lewicy Demokratycznej } & \multicolumn{2}{|c|}{ Prawo i Sprawiedliwość } \\
\hline (P27/26.10/P17/SLD1) & argument & argument & (P27/26.10/P17/PiS1) \\
\hline $\begin{array}{l}\text { (7) Chcemy, aby państwo } \\
\text { finansowało z budżetu } \\
\text { zapłodnienie in vitro, bo } \\
\text { bezpłodność jest choroba. }\end{array}$ & $\begin{array}{l}\text { RO: Państwo musi } \\
\text { zapewnić opiekę } \\
\text { zdrowotną. } \\
\text { ROD: Państwo musi } \\
\text { zapewnić obywate- } \\
\text { lom bezpłatne lecze- } \\
\text { nie chorób. } \\
\text { SK: Bezpłodność jest } \\
\text { chorobą. } \\
\text { K: Państwo musi } \\
\text { finansować leczenie } \\
\text { bezpłodności. } \\
\text { SK: In vitro to lecze- } \\
\text { nie bezpłodności. } \\
\text { K: Państwo musi } \\
\text { finansować in vitro. }\end{array}$ & $\begin{array}{l}\text { RO: Nie wolno eks- } \\
\text { perymentować na } \\
\text { ludziach. } \\
\text { SK: Embrion to } \\
\text { człowiek. } \\
\text { K: Nie wolno eks- } \\
\text { perymentować na } \\
\text { embrionach. } \\
\downarrow \\
\text { RO: Nie wolno eks- } \\
\text { perymentować na } \\
\text { embrionach. } \\
\text { SK: In vitro to ekspe- } \\
\text { rymenty na ludzkich } \\
\text { embrionach. } \\
\text { K: Nie wolno stoso- } \\
\text { wać zapłodnienia } \\
\text { in vitro. }\end{array}$ & $\begin{array}{l}\text { (8) (Projekt SLD ustawy } \\
\text { o planowaniu rodziny } \\
\text { - AFB) [...] znosił zakaz } \\
\text { eksperymentów na } \\
\text { ludzkich embrionach. } \\
\text { Wprowadzat także } \\
\text { szereg innych } \\
\text { niekorzystnych zmian. }\end{array}$ \\
\hline
\end{tabular}

Źródło: opracowanie własne. 
Pojmowanie bezpłodności w kategoriach choroby (konkurujące w polskim kręgu kulturowym z przekonaniem, iż bezpłodność jest rodzajem „dopustu bożego”) prowadzi w następstwie do pozytywnej kwalifikacji zapłodnienia in vitro jako metody leczenia tej choroby. Dla Ligi Polskich Rodzin pozytywna wartość dla tego obiektu jest nie do zaakceptowania - w orientacji ideologicznej tego klubu parlamentarnego stosowanie zabiegów zapłodnienia in vitro jest tożsame z prowadzeniem eksperymentów na ludziach, przez co wywołuje silne negatywne emocje. Ponownie w ramach obiektu zapłodnienie in vitro przywołano inne parametry, jakie należą do jego charakterystyki. W ten sposób obiekt zapłodnienie in vitro wykazał w badanym dyskursie skontrastowanie aksjologiczne. Wobec powyższego należy uznać, iż jest to obiekt ideologiczny.

\section{Podsumowanie}

Przeprowadzona analiza materiału badawczego pod kątem wyodrębnienia obiektów ideologicznych w polskim dyskursie parlamentarnym w okresie 2006-2007 prowadzi do wniosku, że w jego przestrzeni funkcjonowało wiele obiektów ideologicznych. Do ich ukonstytuowania dochodzi wtedy, gdy ma miejsce konfrontacja wartości przypisywanych im przez różne grupy społeczne. Pojawia się wówczas zjawisko definiowania tego samego pojęcia $\mathrm{w}$ różny sposób. Powstałe definicje tworzą reguły ogólne w odtworzonych ciągach argumentacji aksjologicznej. To w nich ujawnia się skonfrontowanie: jedno ugrupowanie dla zachowania ustroju demokratycznego domaga się większego poszanowania głosu opozycji, inne uważa, że władza, która została wybrana przez większość społeczeństwa w uczciwych wyborach, ma prawo sprawować rządy w państwie w sposób, który usatysfakcjonuje właśnie tę większość. W zakresie obiektu ideologicznego „prawa obywatelskie" różnica w ich rozumieniu polega na tym, że jedna grupa oczekuje, że ograniczą one zapędy władzy, prawa obywatelskie regulują więc opozycję obywatele - władza, dla innej prawa obywatelskie obowiązują na linii obywatele - obywatele, rola władzy zaś polega na kontrolowaniu, czy jeden obywatel nie ogranicza swym działaniem praw innego obywatela.

Na zakończenie warto przypomnieć o ograniczeniach metody analizy dyskursu - uzyskane wyniki obowiązują dla zbadanego korpusu tekstów, a ich wykorzystanie w szerszej interpretacji obarczone jest już pewnym ryzykiem błędu. 


\section{Bibliografia}

Awdiejew A., Ideologia. Postawa i komunikacja, [w:] Ideologie w słowach i obrazach, red. I. Kamińska-Szmaj i in., Wrocław 2008, s. 65-72.

Awdiejew A., Habrajska G., Strategie propagandowe i agitacyjne, [w:] Rozmowy o komunikacji 3: Problemy komunikacji społecznej, red. G. Habrajska, Łask 2009, s. 9-54.

Awdiejew A., Habrajska G., Wprowadzenie do gramatyki komunikacyjnej, t. 2, Łask 2006.

Czyżewski M., Kowalski S., Piotrowski A., Wprowadzenie, [w:] Rytualny chaos. Studium dyskursu publicznego, red. M., Czyżewski i in., Warszawa 2010, s. 15-48.

Filipczak A., Mechanizmy manifestowania orientacji aksjologicznej na przykładzie debat parlamentarnych, [w:] Rozmowy o komunikacji 4: Metodologia i praktyka komunikacji społecznej, red. G. Habrajska, Łask 2010, s. 71-86.

Filipczak-Białkowska A., Niedosłowność jako strategia w tekstach politycznych - meto$d y$, funkcje, interpretacja, [w:] Niedosłowność w języku, red. M. Odelski i in., Kraków 2016, s. 103-114.

Filipczak-Białkowska A., Profilowanie obiektu ideologicznego jako strategia manifestowania ideologii $w$ debacie parlamentarnej, [w:] Komunikatywizm w Polsce - wybrane zagadnienia z teorii i praktyki, red. G. Habrajska, Łódź 2011, s. 139-145.

Filipczak-Białkowska A., The Ideology of the Polish Political Discourse in Terms of Communicative Grammar, [w:] Materiały III Międzynarodowej Konferencji Naukowo-Praktycznej "Nauka Szkoła Romana Iwanczenka”, CD, Nationalnyj Tiechnicznyj Uniwersytet Ukrainy, Ukraina 2016, s. 290-300, file://C:/Users/USER/AppData/ Local/Temp/95257-200995-1-SM-1.pdf [dostęp: 12.04.2017].

Habrajska G., Przeżywanie ideologii, [w:] Ideologie w słowach i obrazach, red. I. Kamińska-Szmaj i in., Wrocław 2008, s. 56-64.

Laskowska E., Dyskurs parlamentarny w ujęciu komunikacyjnym, Bydgoszcz 2004.

Laskowska E., Sytuacje komunikacyjne w dyskursach politycznych, [w:] Języka a komunikacja 4: Nowe oblicza komunikacji we współczesnej polszczyźnie, red. G. Szpila, Kraków 2002, s. 175-182.

Lewiński P.H., Neosofistyka. Argumentacja retoryczna w komunikacji potocznej, Wroclaw 2012.

\section{Źródła cytatów}

(P10/16.02/P9/SLD1) Stenogram 10 posiedzenia Sejmu RP z dnia 16 lutego 2006 r., punkt 9 porządku dziennego: Pierwsze czytanie rządowego projektu ustawy o Centralnym Biurze Antykorupcyjnym, pierwsza wypowiedź przedstawiciela klubu parlamentarnego Sojusz Lewicy Demokratycznej.

(P27/26.10/P17/LPR1) Stenogram 27 posiedzenia Sejmu RP z dnia 26 października 2007 r., punkt 17 porządku dziennego: Pierwsze czytanie poselskiego projektu ustawy o zmianie Konstytucji Rzeczypospolitej Polskiej, pierwsza wypowiedź przedstawiciela klubu parlamentarnego Liga Polskich Rodzin. 
(P27/26.10/P17/SLD1) j.w., pierwsza wypowiedź przedstawiciela klubu parlamentarnego Sojusz Lewicy Demokratycznej.

(P27/26.10/P17/PiS1) ) j.w., pierwsza wypowiedź przedstawiciela klubu parlamentarnego Prawo i Sprawiedliwość.

Anita Filipczak-Białkowska

\section{Obiekty ideologiczne w dyskursie parlamentarnym}

Streszczenie

$\mathrm{W}$ artykule przedstawiona jest implementacja metody identyfikowania obiektów ideologicznych w dyskursie na przykładzie debaty parlamentarnej. Analiza prowadzona jest zgodnie z założeniami metodologicznymi gramatyki komunikacyjnej. Wykazała ona, że takie obiekty, jak demokracja, prawo do życia, ograniczenie liczby aborcji czy zapłodnienie in vitro mają status obiektów ideologicznych, bowiem uczestnicy dyskursu odwołują się do różnych parametrów, jakimi charakteryzują się te obiekty. Brak świadomości uczestników dyskursu społeczno-politycznego w zakresie wieloznaczności tych obiektów prowadzi do braku zrozumienia właściwego sensu generowanych w jego zakresie wypowiedzi.

Słowa kluczowe: debata parlamentarna, obiekt ideologiczny, obiekt kulturowy, demokracja

\section{Ideological Objects In Parliamentary Discourse}

Summary

The article presents implementation of method of ideological objects identification in discourse in the example of parliamentary debate. The analysis is being conducted according to methodological assumption of communicative grammar. The analysis of extensive testing material shows, that such objects as democracy, right to life, limitation of abortion and in vitro fertilization have the ideological 


\section{Anita Filipczak-Białkowska}

objects status. That is because participants of the discourse choose different parameters, that are characteristic for this objects. If the participants of social-political discourse have lack of consciousness, that these objects could be ambiguous, they could not understand the right meaning of the statements.

Keywords: parliamentary debate, ideological object, cultural object, democracy

Anita Filipczak-Białkowska jest doktorem językoznawstwa. Pracuje w Zakładzie Teorii Praktyki Komunikacji przy Katedrze Dziennikarstwa i Komunikacji Społecznej Uniwersytetu Łódzkiego. Napisała rozprawę doktorską pt. Manifestowanie orientacji ideologicznej $w$ dyskursie politycznym. Jej zainteresowania badawcze skoncentrowane są wokół nauki o komunikowaniu, ze szczególnym uwzględnieniem perspektywy językoznawczej i psychologicznej. Specjalizuje się w problematyce wywierania wpływu na ludzi. 